\title{
CHEMOSPHERE
}

\section{Comparison of a rhizosphere-based method with other one-step extraction methods for assessing the bioavailability of soil metals to wheat}

\author{
Mu-Hua Feng, Xiao-Quan Shan *, Shu-Zhen Zhang, Bei Wen \\ Key Laboratory of Environmental Chemistry and Ecotoxicology, Research Center for Eco-Environmental Sciences, \\ Chinese Academy of Sciences, P.O. Box 2871, Beijing 100085, China
}

Received 24 June 2004; received in revised form 17 October 2004; accepted 22 November 2004

\begin{abstract}
There is no method recognized as a universal approach for evaluation of bioavailability of heavy metals in soil. Based on the simulation of the rhizosphere soil conditions and integration of the combined effects of root-soil interactions as a whole, a rhizosphere-based method has been proposed. Wet fresh rhizosphere soil was extracted by lowmolecular-weight organic acids (LMWOAs) to fractionate metal fractions of soil pools, which were then correlated with the metal contents of wheat roots and shoots. The rhizosphere-based method was compared with other one-step extraction methods using DTPA, EDTA, $\mathrm{CaCl}_{2}$, and $\mathrm{NaNO}_{3}$ as extractants and the first step of the Community Bureau of Reference (BCR) method. Simple correlation and stepwise multiple regression analysis were used for the comparison. Simple correlation indicated that the extractable $\mathrm{Cu}, \mathrm{Zn}, \mathrm{Cr}$, and $\mathrm{Cd}$ of soils by the rhizosphere-based method were significantly correlated with the metal contents of wheat roots. For DTPA, BCR1 and EDTA methods there was a relatively poor correlation between the extractable $\mathrm{Cu}, \mathrm{Zn}$ and $\mathrm{Cd}$ of soil and metal contents of wheat roots. Stepwise multiple regression analysis revealed that the equation of the rhizosphere-based method was the simplest one, and no soil properties variables needed to be added. In contrast, the equations of other one-step extraction methods were more complicated, and soil properties variables needed to be entered. The most distinct feature of the rhizosphere-based method was that the recommended method was suitable for acidic, neutral and near alkaline soils. However, the DTPA and EDTA extraction methods were suitable for calcareous soils only-or-only for acidic soils. The $\mathrm{CaCl}_{2}$, and $\mathrm{NaNO}_{3}$ extraction methods were only suitable for exchangeable metals. In short, the rhizosphere-based method was the most robust approach for evaluation of bioavailability of heavy metals in soils to wheat.
\end{abstract}

(C) 2004 Elsevier Ltd. All rights reserved.

Keywords: Rhizosphere; Low-molecular-weight organic acids; Bioavailability; Heavy metals in soil; Wheat

\footnotetext{
* Corresponding author. Tel.: +8610 62923560; fax: +8610 62923563.

E-mail address: xiaoquan@mail.rcees.ac.cn (X.-Q. Shan).
}

\section{Introduction}

Many efforts have been made to estimate bioavailability of metals in soils to plants. The most important approaches include the free ion activity model (FIAM) (Morel, 1983; McLaughlin et al., 1997; Hudson, 1998; 
Errécalde and Campbell, 2000), the correlation between the labile metals in soil pools determined by single or sequential extraction methods and their accumulation in plants (Haq et al., 1980; Novozamsky et al., 1993; Shan et al., 2003), the isotope dilution exchange method (Collins et al., 2003) and the diffusive gradients in thin films (DGT) (Zhang et al., 1998, 2001).

Linear correlations between various indicators of metal bioavailability and the metal content in plant parts are often used for identifying the best-suited method of assessment for soil testing procedures. Both single and sequential extraction approaches are used for fractionation of metals in soil pools. Ethylenediamine tetraacetic acid (EDTA) (0.005-1 M) acts as a chelating agent, and EDTA can form stable chelates with many metal ions (Haq et al., 1980; Hammer and Keller, 2002; Chaignon et al., 2003). Diethylenetriaminepentaacetic acid (DTPA) (0.005 M) (Haq et al., 1980; Norvell, 1984; Chaignon et al., 2003) is most suitable for calcareous soils, as it is buffered at a pH 7.3 and therefore prevents $\mathrm{CaCO}_{3}$ from dissolution and release of occluded metals. The DTPA extraction method is chosen to minimize dissolution of carbonates, although uncertainty concerning the dissolution of iron and aluminum compounds remains (Novozamsky et al., 1993). Sodium nitrate and ammonium nitrate are also widely used for single extraction (Whitten and Ritchie, 1991). The use of $\mathrm{CaCl}_{2}$ is also recommended due to the same salt concentration as the average $\mathrm{Ca}^{2+}$ concentration in soil solution and ability of $\mathrm{Ca}^{2+}$ to extract other adsorbed cations in soils (Novozamsky et al., 1993). The Community Bureau of Reference (BCR, now Standards, Measurements and Testing Programme of the European Committee) launched a project to coordinate measurements of the extractable trace metal contents in soil and sediments (Quevauviller et al., 1994). More recently, this method has been applied to estimate bioavailability, but no consistent data have been obtained (Qian et al., 1996; Sauvé et al., 1996; Shan et al., 2003). Gleyzes et al. (2002) comprehensively reviewed the single and sequential fractionation methods. Low-molecular-weight organic acids (LMWOAs) are important plant exudates. It should also be stressed that parts of LMWOAs normally found in the rhizosphere are microbial metabolites. It is for instance often considered that acetic and lactic acids are more likely originating from rhizosphere bacteria (Jones, 1998). LMWOAs play an important role in coping with nutrient deficiencies, metal tolerance and plant-microbe interactions operating at the root-soil interface (López-Bucio et al., 2000). In our previous study, LMWOAs were used to predict the bioavailability of heavy metals and rare earth elements (REEs) in soil pools to plants (Shan et al., 2003). In order to further understand whether the LMWOAs extraction method can be more widely used for bioavailability, we studied the effects of LMWOAs on release of REEs and heavy metals from soils (Shan et al., 2002; Qin et al., 2004). The results indicated that metals could be easily released from soils in the presence of LMWOAs. In addition, soil and hydroponic culture experiments also verified that LMWOAs enhanced the uptake of lanthanum by wheat roots (Wang et al., 2004) and barley roots (Han et al., 2004). LMWOAs also increased the accumulation of light REEs in perennial fern (Wang et al., 2004). All these results demonstrated that organic acids were involved in soil-root interactions, which rationalize the rhizosphere-based method for assessing the bioavailability of metals in soil to plants.

Although a good progress has been made in bioavailability methods, no universally applicable approach has been recognized. The derived data from the correlation methods are inconsistent and make interpretations difficult (Sauvé et al., 1996). It was ascribed to the poor simulation of the conditions of field-grown plants, while the combined-effects of soil-root interactions have not been fully integrated in the current methods of bioavailability.

It has been progressively understood that many factors influence the bioavailability, including soil properties and plant species. There is no simple cause-effect relationship between the metal bound with a particular geochemical phase and metal uptake by plants. It is especially true that the rhizosphere-plant interactions influence the metal bioavailability, and therefore the development of new methods for evaluation of bioavailability should be based on the rhizosphere-plant interactions. The principles of new bioavailability methods must simulate the real field conditions as close as possible, and also simulate the combined effects of rhizosphere-root interactions as a whole. The key parameters of new bioavailability method are the uses of fresh rhizosphere soil and LMWOAs as extractant. Hereafter, this method is referred to as rhizosphere-based extraction method.

To our knowledge a systematic comparison between different extraction methods for assessing the bioavailability of soil metals is lacking. Therefore, the aim of the present study was to compare the rhizosphere-based method with other one-step extraction methods using DTPA, EDTA, $\mathrm{CaCl}_{2}, \mathrm{NaNO}_{3}$ as extractants and the first step of the Community Bureau of Reference (BCR) method. Simple correlation and stepwise multiple regression analysis were used for comparison.

\section{Materials and methods}

\subsection{Soil sample}

Sixteen $A_{p}$ horizon cultivated soil samples were collected from different provinces of China, which represented a spectrum of typical Chinese soils (Gong, 
1999) with various physical and chemical properties. The soil samples were air dried, homogenized and ground to pass through a $1 \mathrm{~mm}$ nylon fiber sieve, and stored for subsequent analysis. Organic matter (OM) was determined by the Walkley-Black procedure (Nelson and Sommers, 1982). Soil $\mathrm{pH}$ was measured at soil to $0.01 \mathrm{M} \mathrm{CaCl}_{2}$ solution of $1: 1(\mathrm{w} / \mathrm{v})$. Cation-exchange capacity (CEC) was determined by the $\mathrm{BaCl}_{2}$ method
(Hendershot and Duquette, 1986). Amorphous iron oxides (amorphous-Fe) were determined by ammoniumoxalate extraction method (Blakemore et al., 1987). Crystalline iron oxides (crystal-Fe) were determined by the oxalate-ascorbic acid extraction method of Shuman (Shuman, 1982). The selected soil properties are presented in Table 1. The total concentrations of metals in soils are given in Table 2.

Table 1

Selected properties of soils

\begin{tabular}{|c|c|c|c|c|c|c|c|}
\hline \multirow[t]{2}{*}{ Site } & \multirow[t]{2}{*}{ Taxonomy } & \multirow[t]{2}{*}{$\mathrm{pH}$} & \multirow{2}{*}{$\begin{array}{l}\mathrm{CEC}^{\mathrm{a}} \\
\mathrm{cmol} \mathrm{kg}^{-1}\end{array}$} & \multirow[t]{2}{*}{$\mathrm{OM}^{0} \%^{\mathrm{b}}$} & \multicolumn{2}{|l|}{$\mathrm{Fe}$} & \multirow{2}{*}{$\begin{array}{l}\mathrm{MnO}_{2} \\
\mathrm{~g} \mathrm{~kg}^{-1}\end{array}$} \\
\hline & & & & & Amor $\%{ }^{\mathrm{c}}$ & $\mathrm{Cry} \%{ }^{\mathrm{d}}$ & \\
\hline Heilongjiang & Isohumisols & 7.34 & 20.2 & 6.86 & 0.73 & 18.3 & 4.02 \\
\hline Jilin & Isohumisols & 5.65 & 14.0 & 2.56 & 0.70 & 26.6 & 6.58 \\
\hline Gansu & Isohumisols & 6.55 & 41.2 & 0.96 & 0.26 & 21.9 & 3.27 \\
\hline Neimenggu & Luvisols & 6.32 & 56.8 & 3.81 & 0.26 & 13.1 & 3.09 \\
\hline Shanxi & Luvisols & 7.29 & 21.9 & 4.12 & 0.27 & 19.4 & 2.21 \\
\hline Beijing & Cambisols & 6.91 & 15.7 & 1.35 & 0.37 & 15.5 & 4.09 \\
\hline Shandong & Luvisols & 6.75 & 18.0 & 0.98 & 0.47 & 16.7 & 4.74 \\
\hline Jiangsu & Luvisols & 6.37 & 22.3 & 0.68 & 0.47 & 16.1 & 3.62 \\
\hline Anhui & Luvisols & 5.16 & 25.0 & 2.09 & 0.66 & 18.0 & 3.54 \\
\hline Hubei & Luvisols & 6.67 & 22.8 & 0.92 & 1.04 & 32.9 & 5.25 \\
\hline Fujian & Ferralisols & 6.09 & 5.1 & 1.81 & 0.54 & 13.2 & 3.53 \\
\hline Jiangxi & Ferrisols & 4.70 & 14.2 & 0.80 & 0.29 & 24.4 & 1.90 \\
\hline Yunnan & Ferrisols & 6.64 & 15.5 & 2.23 & 0.97 & 29.9 & 5.25 \\
\hline Chengdu & Cambisols & 6.50 & 42.6 & 1.03 & 0.54 & 22.0 & 4.82 \\
\hline Guizhou & Cambisols & 6.30 & 51.3 & 6.76 & 1.04 & 32.9 & 6.37 \\
\hline Xinjiang & Aridisols & 7.44 & 74.0 & 0.90 & 0.26 & 14.1 & 4.14 \\
\hline
\end{tabular}

${ }^{\mathrm{a}} \mathrm{CEC}=$ cation exchange capacity.

${ }^{\mathrm{b}} \mathrm{OM}=$ organic matter.

c Amor-Fe $=$ amorphous iron oxide.

${ }^{\mathrm{d}} \mathrm{Cry}-\mathrm{Fe}=$ crystalline iron oxide.

Table 2

Total concentrations of metals in soils $\left(\mathrm{mg} \mathrm{kg}^{-1}\right)$

\begin{tabular}{|c|c|c|c|c|c|c|c|}
\hline \multirow[t]{2}{*}{ Site } & \multicolumn{6}{|l|}{ Metal } & \multirow{2}{*}{$\begin{array}{l}\text { Soil } \\
\text { quality }^{\mathrm{a}}\end{array}$} \\
\hline & $\mathrm{Cr}$ & $\mathrm{Ni}$ & $\mathrm{Cu}$ & $\mathrm{Zn}$ & $\mathrm{Cd}$ & $\mathrm{Pb}$ & \\
\hline Heilongjiang & 52.8 & 43.3 & 83.8 & 215.3 & 0.306 & 39.8 & I \\
\hline Jilin & 76.1 & 37.7 & 80.7 & 150.3 & 0.595 & 27.3 & II \\
\hline Gansu & 44.3 & 61.4 & 41.7 & 38.5 & 0.200 & 45.1 & II \\
\hline Neimenggu & 32.7 & 48.9 & 43.6 & 156.3 & 0.462 & 21.9 & II \\
\hline Shanxi & 25.3 & 42.0 & 31.9 & 67.2 & 0.221 & 29.7 & I \\
\hline Beijing & 33.6 & 30.9 & 37.5 & 105.5 & 0.230 & 24.3 & I \\
\hline Shandong & 32.2 & 27.3 & 60.9 & 172.4 & 0.335 & 51.2 & I \\
\hline Jiangsu & 53.8 & 31.6 & 51.4 & 163.9 & 0.487 & 25.7 & II \\
\hline Anhui & 54.2 & 23.1 & 57.2 & 180.6 & 0.401 & 42.9 & I \\
\hline Hubei & 53.8 & 33.8 & 62.3 & 254.5 & 0.419 & 22.4 & II \\
\hline Fujian & 4.2 & 10.0 & 96.7 & 509.5 & 0.282 & 86.6 & III \\
\hline Jiangxi & 45.3 & 20.8 & 48.5 & 270.0 & 0.217 & 36.7 & II \\
\hline Yunnan & 36.2 & 27.4 & 116.3 & 138.6 & 0.875 & 70.4 & II \\
\hline Chengdu & 49.5 & 43.8 & 141.7 & 213.7 & 0.292 & 32.5 & II \\
\hline Guizhou & 145.1 & 69.1 & 83.1 & 409.3 & 0.738 & 51.2 & III \\
\hline Xinjiang & 42.8 & 95.4 & 45.7 & 97.5 & 0.333 & 35.8 & III \\
\hline
\end{tabular}

a Classification of soil quality based on GB15618-1995 (China). Grade I: natural background level; Grade II: lightly polluted; Grade III: mildly polluted. 


\subsection{Pot experiments and sample preparation}

Soil samples $(0.50 \mathrm{~kg})$ were fertilized with $0.4 \mathrm{~g} / \mathrm{kg}$ each of $\mathrm{N}, \mathrm{P}, \mathrm{K}$ as $\mathrm{KH}_{2} \mathrm{PO}_{4}$ and $\left(\mathrm{NH}_{4}\right)_{2} \mathrm{CO}_{3}$ and $\mathrm{KNO}_{3}$ in solution, homogenized and incubated for 1 week before planting. Winter wheat (Triticum aestivum L.) seeds were soaked in distilled water for $24 \mathrm{~h}$ and then placed on moist filter paper to germinate. Seedlings were sown in each pot and thinned to 15 seedlings per pot after 2 weeks. Water loss was compensated for by daily addition of deionized water. Six weeks after planting, seedlings were harvested. Wheat shoots and roots were first rinsed thoroughly with tap water and then with de-ionized water. Roots were cut off. Roots and shoots were dried in an oven at $65^{\circ} \mathrm{C}$ for 2 days to constant weight for determination of metals.

Rhizosphere soil (adhering to the root system) was obtained by gently shaking off the loosely bound soil first and then was separated from the roots by a more vigorous shaking or by hands. Rhizosphere soil was subjected to metal fractionation immediately or placed in polyethylene bags, and stored in a refrigerator at $-18^{\circ} \mathrm{C}$ for further metal fractionation.

\subsection{Extraction procedure}

Moist rhizosphere soils were used for all extraction procedures in order to avoid the speciation change during drying process. The extraction procedures using $0.05 \mathrm{M}$ EDTA, $0.005 \mathrm{M}$ DTPA, $0.01 \mathrm{M} \mathrm{CaCl}_{2}, 0.1 \mathrm{M}$ $\mathrm{NaNO}_{3}$, and the first step of a three-step sequential extraction procedure recommended by the Community Bureau of Reference (BCR), now Standards, Measurements and Testing Programme of European Community, were performed. The detailed operations were identical to the references (Table 3), with the exception that the moist rhizosphere soils were used.
The rhizosphere-based extraction protocol was performed as below: $2.00 \mathrm{~g}$ soil was mixed with $20 \mathrm{ml}$ of acetic, lactic, citric, malic, and formic acids (two drops of toluene was added as a biocide) in $50 \mathrm{ml}$ pre-cleaned plastic centrifuge tube. The total concentration of these organic acids was $10 \mathrm{mM}$, and their molar concentration ratio was $4: 2: 1: 1: 1$. The soil suspension was shaken by an end-over-end shaker for $16 \mathrm{~h}$, and centrifuged at $3000 \times g$ for $10 \mathrm{~min}$. An aliquot of $5 \mathrm{ml} \mathrm{supernatant}$ was removed immediately by a transfer pipette to $10 \mathrm{ml}$ volumetric flask and diluted to volume with $2 \%$ $\mathrm{HNO}_{3}$. The extracts obtained were used for the determination of heavy metals. The soil moisture contents were measured by drying soil at $105 \pm 2{ }^{\circ} \mathrm{C}$ for $6 \mathrm{~h}$ to constant weight. All extraction procedures were carried out in triplicate, including the blanks.

\subsection{Determination of heavy metals}

Total concentrations of heavy metals in soil and in plants were determined by inductively coupled plasma mass spectrometry (ICP-MS, PQ3, Fisons Instruments, UK) after digestion of soil and plant samples in $3 \mathrm{ml}$ of $\mathrm{HNO}_{3} / \mathrm{HClO}_{4} / \mathrm{HF}(1+1+1)$ mixture in PTFE vessel under high-pressure conditions (Zhang and Shan, 1997). The concentrations of heavy metals in the extracted soil solutions were determined after appropriate dilution with $2 \% \mathrm{HNO}_{3}$.

\subsection{Reagents and glassware}

All reagents used were of analytical reagent grade or better. All glassware and plastic containers were previously soaked into $1: 2(\mathrm{v} / \mathrm{v}) \mathrm{HNO}_{3}$ overnight and rinsed thoroughly with deionized distilled water before use. High purity of water $(18 \mathrm{M} \Omega \mathrm{cm})$ was prepared by double distillation of deionized water in a fused quartz still (Westdeutsche Quarzschmelze, Geesthacht, Germany).

Table 3

Extraction procedures used in the study

\begin{tabular}{lll}
\hline Extraction method & Procedure & Refs. \\
\hline EDTA & $2.0 \mathrm{~g}$ soil in $20 \mathrm{ml} 0.05 \mathrm{M}$ EDTA adjusted by ammonia solution & Wear and Evans (1968) \\
& to $\mathrm{pH} 7.0$, shaking for $1 \mathrm{~h}$ & Lindsay and Norvell (1978) \\
DTPA & $10.0 \mathrm{~g}$ soil in $20 \mathrm{ml} 0.005 \mathrm{M} \mathrm{DTPA}+0.01 \mathrm{M} \mathrm{TEA}+0.01 \mathrm{M}$ & \\
& $\mathrm{CaCl}$ adjusted to $\mathrm{pH} 7.3$, shaking for $2 \mathrm{~h}$ & Novozamsky et al. (1993) \\
$\mathrm{CaCl}_{2}$ & $2.0 \mathrm{~g}$ soil in $20 \mathrm{ml} 0.01 \mathrm{M} \mathrm{CaCl}$, shaking for $3 \mathrm{~h}$ & Gupta and Aten (1993) \\
$\mathrm{NaNO}_{3}$ & $8.0 \mathrm{~g}$ soil in $20 \mathrm{ml} 0.1 \mathrm{M} \mathrm{NaNO}$, shaking for $2 \mathrm{~h}$ & Ure et al. (1993) \\
$\mathrm{BCR}^{\mathrm{a}}$ & $1.0 \mathrm{~g}$ soil in $20 \mathrm{ml} 0.11 \mathrm{M}$ acetic acid, shaking for $16 \mathrm{~h}$ & This work \\
RHIZO $^{\mathrm{b}}$ & $2.0 \mathrm{~g}$ soil in $20 \mathrm{ml}$ LMWOAs, total concentration of acetic, & \\
& lactic, citric, malic, and formic acids was $0.01 \mathrm{M}$, their molar ratio & \\
\hline
\end{tabular}

\footnotetext{
${ }^{\mathrm{a}} \mathrm{BCR} 1=$ the first step of European Community Bureau of Reference.

b $\mathrm{RHIZO}=$ rhizosphere-based method.
} 


\subsection{Statistical analysis}

Statistical analyses were performed using SPSS 11.5 for Windows (SPSS Inc., USA). Pearson correlation coefficients were determined by correlating metal contents in roots and shoots with extractable heavy metals from soils by various extraction methods.

Forward stepwise multivariate regression was used to derive best-fit models of metal concentrations in plants to soil properties and extractable metals in soils. The variance inflation factor (VIF), the condition indices and the regression coefficient variance-decomposition matrix were also assessed in order to evaluate the collinearity between independent variables. Collinearity becomes an issue when values of VIF exceed 10.0 and condition index is over 30 .

\section{Results and discussion}

\subsection{Optimization of rhizosphere-based extraction procedure}

In our separate study (Li et al., 2003) the concentrations of acetic, lactic, malic and formic acids in rhizosphere soil and plant roots were determined, which ranged from below the detection limits of capillary zone electrophoresis to several $\mathrm{mM}$. Other studies have also reported that the most abundant monocarboxylic acids (such as formic, acetic and propionic acids) were up to $1 \mathrm{mM}$ in soil solutions (Jones, 1998; Strobel, 2001). The concentration of organic acids in roots cell vacuoles was usually ranged from 5 to $50 \mathrm{mM}$ (Ryan et al., 2001). In order to study the effect of LMWOAs concentrations on extractable heavy metals from soils a series of experiments were performed. The total concentrations of acetic, lactic, citric, malic, and formic acids varied from 0.4 to $100 \mathrm{mM}$, and their molar ratio of $4: 2: 1: 1: 1$ was chosen. Sixteen moist rhizosphere soils collected from different provinces of China after wheat planting was used for the optimization of LMWOAs extraction. All extractions were repeated in triplicate. The $\mathrm{pH}$ of the soil solution after extraction was monitored. No attempts, however, were made to maintain the $\mathrm{pH}$ during LMWOAs extraction for different soils. The errors of the determinations of heavy metals were less than $5 \%$ $(n=3)$ for each soil.

The relationship between the LMWOAs concentrations and extractable metals from soils were quite similar for all soils. Here taking Heilongjiang soil as an example, and the results are shown in Fig. 1. Generally, the extracted metals increased with increasing LMWOAs concentrations. Over the total concentration range of 1-10 mM LMWOAs the extractable metals increased very slowly. After that limit the extractable metals increased rapidly with further increasing LMWOAs con-

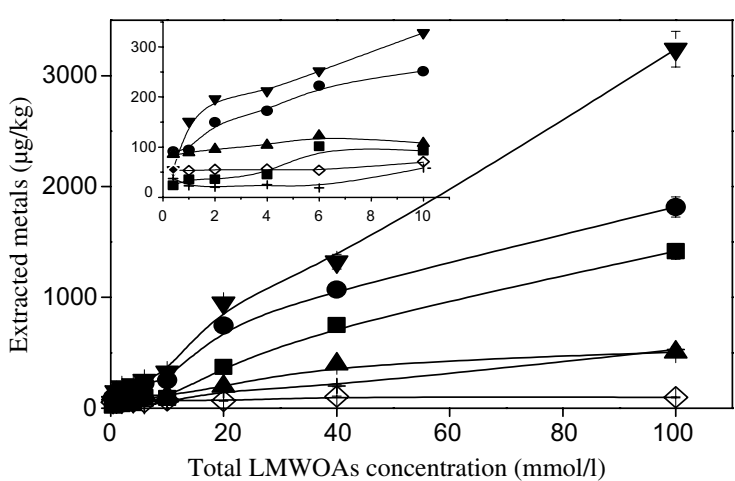

Fig. 1. The extractable metals from Heilongjiang soil as a function of the concentration of LMWOAs (acetic:lactic:citric:malic:formic acids at molar ratio $=4: 2: 1: 1: 1)$. $(\mathbf{\square})$ : $\mathrm{Cr} ;(\boldsymbol{O})$ : $\mathrm{Ni} ;(\boldsymbol{\Delta}): \mathrm{Cu} ;(\boldsymbol{\nabla}): \mathrm{Zn} ;(\diamond): \mathrm{Cd} ;(+): \mathrm{Pb}$.

centrations. And it seems that no equilibrium was reached at the concentration range of LMWOAs tested. The reason for this was probably that higher concentration of LMWOAs might attack soil minerals, resulting in the release of heavy metals associated with various geochemical phases of soil. Considering a concentration gradient of LMWOAs from root surface to soil solution, and a short-term extraction for simulation of long-term reaction in the rhizosphere the total concentration of $10 \mathrm{mM}$ LMWOAs was chosen as an extractant in the remainder of experiments.

The effect of extraction time on the extractable metals and soil solution $\mathrm{pH}$ was also studied. The results demonstrated that the extractable metals reached equilibrium after extraction time of $4 \mathrm{~h}$. The $\mathrm{pH}$ of extracted soil solutions remained unchanged after extraction time of $12 \mathrm{~h}$. In the remainder of this study an extraction time of $16 \mathrm{~h}$ was chosen.

\subsection{Comparison of extractable metals using various extraction methods}

In this study, the rhizosphere-based extraction method was compared with other one step extraction methods using DTPA, EDTA, $\mathrm{CaCl}_{2}$, and $\mathrm{NaNO}_{3}$ as extractants and the first step of BCR (BCR1) method. The range and mean of the extractable metals with these methods are shown in Table 4. The comparison of the extractable metal concentrations was performed using $T$ test with $95 \%$ confidence intervals. Generally, the extractable metals followed the descending order EDTA $\approx \mathrm{BCR} 1>$ DTPA $>$ rhizosphere-based method $\approx \mathrm{CaCl}_{2}>\mathrm{NaNO}_{3}$. Chelating agents of EDTA and DTPA and high concentration of acetic acid (BCR1) extracted more metals from soils than $\mathrm{CaCl}_{2}$ and $\mathrm{NaNO}_{3}$. The extractable metals with the rhizosphere-based method were in between. 
Table 4

Ranges and means of extractable heavy metals of rhizosphere soils $(\mu \mathrm{g} / \mathrm{kg})(n=16)$

\begin{tabular}{|c|c|c|c|c|c|c|c|c|c|c|c|c|}
\hline \multirow[t]{2}{*}{ Element } & \multicolumn{2}{|l|}{$\mathrm{RHIZO}^{\mathrm{a}}$} & \multicolumn{2}{|l|}{ DTPA } & \multicolumn{2}{|l|}{$\mathrm{BCR} 1^{\mathrm{b}}$} & \multicolumn{2}{|l|}{ EDTA } & \multicolumn{2}{|l|}{$\mathrm{CaCl}_{2}$} & \multicolumn{2}{|l|}{$\mathrm{NaNO}_{3}$} \\
\hline & Range & Mean & Range & Mean & Range & Mean & Range & Mean & Range & Mean & Range & Mean \\
\hline $\mathrm{Cr}$ & $32.0-224$ & 67.4 & $8.13-66.4$ & 31.9 & $55.1-1666$ & 477 & $123-756$ & 383 & $0.11-15.1$ & 4.32 & $4.24-22.3$ & 9.06 \\
\hline $\mathrm{Ni}$ & $45.4-900$ & 205 & $54.8-916$ & 331 & $178-6168$ & 2115 & $164-5044$ & 1249 & $9.92-499$ & 75.1 & $10.6-77.9$ & 32.8 \\
\hline $\mathrm{Cu}$ & $36.0-1215$ & 186 & $127-5417$ & 1211 & $2.50-1642$ & 579 & 53.6-7996 & 3389 & $2.42-1595$ & 182.5 & $5.95-95.8$ & 32.5 \\
\hline $\mathrm{Zn}$ & $25.2-1110$ & 273 & $248-9350$ & 1666 & $158-28606$ & 4775 & 409-18269 & 3653 & $8.47-5935$ & 558 & $1.19-182$ & 36.8 \\
\hline $\mathrm{Cd}$ & $17.2-44.9$ & 26.8 & $19.6-634$ & 94.0 & $4.70-1913$ & 290 & $61.7-829$ & 162 & $17.4-95.5$ & 35.6 & $0.61-105$ & 22.8 \\
\hline $\mathrm{Pb}$ & $0.405-88.7$ & 16.2 & $378-4681$ & 1409 & 29.7-1019 & 297 & 799-9221 & 3724 & $0.56-1558$ & 236 & $1.37-34.5$ & 8.82 \\
\hline
\end{tabular}

${ }^{\text {a }}$ RHIZO = rhizosphere-based method.

${ }^{\mathrm{b}} \mathrm{BCR} 1=$ the first step of European Community Bureau of Reference.

The reasons for this extraction order are easily understood. EDTA is a strong chelating reagent and has been reported to remove both the organically bound metals and metals occluded in oxides and secondary clay minerals in part (Payá-Pérez et al., 1993). EDTA is a non-specific extractant, and it can extract labile and non-labile fractions (Bermond et al., 1998). A higher concentration of $0.11 \mathrm{M}$ acetic acid was used in the first step of the BCR method. Acetic acid could extract organic matter bound metals in part (Payá-Pérez et al., 1993), and acetic acid was able to release most of metals associated with calcium carbonate, and minerals (kaolinite, potassium felspar and ferrihydrite) (Whalley and Grant, 1994). DTPA was originally developed to identify near-neutral and calcareous soils with insufficient transition metals (Lindsay and Norvell, 1978). Iron and manganese oxides are potentially extracted from acidic soils by DTPA (O'Connor, 1988). As far as the soil background electrolyte solutions were concerned, easily exchangeable metals could be extracted with $\mathrm{NaNO}_{3}$ and $\mathrm{CaCl}_{2}$ (McBride et al., 2003). Lower con- centrations of metals were extracted with $\mathrm{NaNO}_{3}$ than with $\mathrm{CaCl}_{2}$, because the monovalent cations exert weak competition with the adsorption sites on organic matter (Novozamsky et al., 1993). For rhizospherebased method, complexation of metals by organic acids plays an important role in controlling metal solubility (Cieśliński et al., 1998; Naidu and Harter, 1998; Shan et al., 2002; Qin et al., 2004). Metals extracted by the rhizosphere-based method correspond to the mobile fractions in soil solution (Naidu and Harter, 1998), which are responsible for the short-term available pool (Cieśliński et al., 1998).

\subsection{Comparison of the rhizosphere-based method with other extraction methods for bioavailability using simple correlation analysis}

The relationship between the extractable metals in soil solutions and metal accumulation in wheat roots and shoots are summarized in Table 5. Generally, the correlation coefficients between extractable metals in soil

Table 5

Linear correlation coefficients $(r)$ between metal concentrations in shoots and roots and extracted metals from soils by different extraction methods $(n=16)$

\begin{tabular}{|c|c|c|c|c|c|c|c|}
\hline & Element & $\mathrm{RHIZO}^{\mathrm{a}}$ & DTPA & $\mathrm{BCR} 1^{\mathrm{b}}$ & EDTA & $\mathrm{CaCl}_{2}$ & $\mathrm{NaNO}_{3}$ \\
\hline \multirow[t]{6}{*}{ Shoot } & $\mathrm{Cr}$ & 0.306 & -0.266 & 0.063 & 0.273 & 0.170 & -0.265 \\
\hline & $\mathrm{Ni}$ & 0.197 & 0.259 & -0.002 & 0.192 & $0.787^{* * *}$ & 0.386 \\
\hline & $\mathrm{Cu}$ & $0.823^{* * *}$ & 0.418 & $0.429^{*}$ & 0.352 & 0.006 & $0.795^{* * *}$ \\
\hline & $\mathrm{Zn}$ & $0.690^{* *}$ & $0.496^{*}$ & $0.573^{*}$ & $0.500^{*}$ & 0.412 & 0.030 \\
\hline & $\mathrm{Cd}$ & $0.792^{* * *}$ & $0.548^{*}$ & $0.498^{*}$ & $0.533^{*}$ & 0.134 & -0.241 \\
\hline & $\mathrm{Pb}$ & $0.438^{*}$ & 0.290 & 0.417 & -0.068 & $0.448^{*}$ & 0.144 \\
\hline \multirow[t]{6}{*}{ Root } & $\mathrm{Cr}$ & $0.519^{*}$ & 0.033 & 0.257 & -0.216 & $0.540^{*}$ & 0.229 \\
\hline & $\mathrm{Ni}$ & -0.235 & -0.265 & 0.415 & 0.107 & -0.113 & -0.158 \\
\hline & $\mathrm{Cu}$ & $0.731^{* * *}$ & $0.524^{*}$ & $0.541^{*}$ & 0.381 & -0.093 & $0.676^{* *}$ \\
\hline & $\mathrm{Zn}$ & $0.733^{* * *}$ & $0.512^{*}$ & $0.590^{*}$ & $0.747^{* * *}$ & $0.762^{* * *}$ & 0.273 \\
\hline & $\mathrm{Cd}$ & $0.796^{* * *}$ & $0.738^{* * *}$ & $0.724^{* *}$ & $0.765^{* * *}$ & 0.225 & -0.232 \\
\hline & $\mathrm{Pb}$ & 0.037 & 0.099 & 0.043 & 0.106 & -0.013 & 0.333 \\
\hline
\end{tabular}

${ }^{*},{ }^{* *}$, and ${ }^{* * *}=$ the probability level of $p<0.1, p<0.01$, and $p<0.001$, respectively.

${ }^{a}$ RHIZO = rhizosphere-based method.

${ }^{\mathrm{b}} \mathrm{BCR} 1=$ the first step of European Community Bureau of Reference. 
pools and metals in roots are better than that in shoots (Table 5). This was in agreement with the criticism by Chaignon et al. (2003) that metals in shoots are not a good indicator of metal bioavailability. Thus, the following discussion was limited to the relationship between metals in roots and in soil pools.

When comparing the correlation coefficients obtained by the rhizosphere-based method with that obtained by DTPA, BCR1, EDTA, $\mathrm{CaCl}_{2}$, and $\mathrm{NaNO}_{3}$ extraction methods, the rhizosphere-based method was preferred to evaluate metal bioavialability. For the rhizosphere-based method a good correlation was obtained between the extractable $\mathrm{Cr}, \mathrm{Cu}, \mathrm{Zn}$ and $\mathrm{Cd}$ in soil pools and their contents of wheat roots. The correlation coefficients were $0.519^{*}, 0.731^{* * *}, 0.733^{* * *}$ and $0.796^{* * *}$ for $\mathrm{Cr}, \mathrm{Cu}, \mathrm{Zn}$ and $\mathrm{Cd}$, respectively. When DTPA, BCR 1 and EDTA extraction methods were used, there was a good correlation between the extractable $\mathrm{Cu}, \mathrm{Zn}$ and $\mathrm{Cd}$ and their contents of wheat roots, but the correlation coefficients were lower, especially for $\mathrm{Cu}$ and $\mathrm{Zn}$. For the $\mathrm{CaCl}_{2}$ extraction method only extractable $\mathrm{Cr}$ and $\mathrm{Zn}$ were correlated with those metals in roots $\left(r=0.540^{*}\right.$ to $\left.0.762^{* * *}\right) . \mathrm{NaNO}_{3}$ extraction method was only good for assessing the bioavailability of $\mathrm{Cu}$ $\left(r=0.676^{* * *}\right)$. These results were consistent with Hammer and Keller (2002), who suggested that plant appeared to take up heavy metals from other pools than the $\mathrm{NaNO}_{3}$-extractable one.

\subsection{Superiority of the rhizosphere-based method over other extraction ones to different types of soils}

As it has already been pointed out before that the DTPA extraction method is most suitable for calcareous soils, the EDTA extraction method was originally developed for acidic soils, the $\mathrm{NaNO}_{3}$ and $\mathrm{CaCl}_{2}$ extraction methods are suitable for easily exchangeable heavy metals (Hammer and Keller, 2002). In order to compare the suitability of the rhizosphere-based method for different types of soils the 16 soils were divided into two groups based on soil $\mathrm{pH}$. Soils of $\mathrm{pH} \leqslant 6.5$ were referred to as acidic soils, and soils of $\mathrm{pH}>6.5$ as neutral and near alkaline soils. Generally, the extractable metals from the acidic soils were higher than that from the neutral and near alkaline soils, and the metal contents in wheat roots grown in the acidic soils were also higher than that in the neutral and near alkaline soils (data not shown).

A simple correlation analysis was performed between the extractable metals by different extraction methods from the acidic, neutral and near alkaline soils, and metal contents of wheat roots, separately. The comparison results are shown in Table 6. The extractable $\mathrm{Cr}, \mathrm{Cu}, \mathrm{Zn}$, and $\mathrm{Cd}$ from both types of soils by the rhizospherebased method were significantly correlated with their contents of wheat roots. These results suggested that

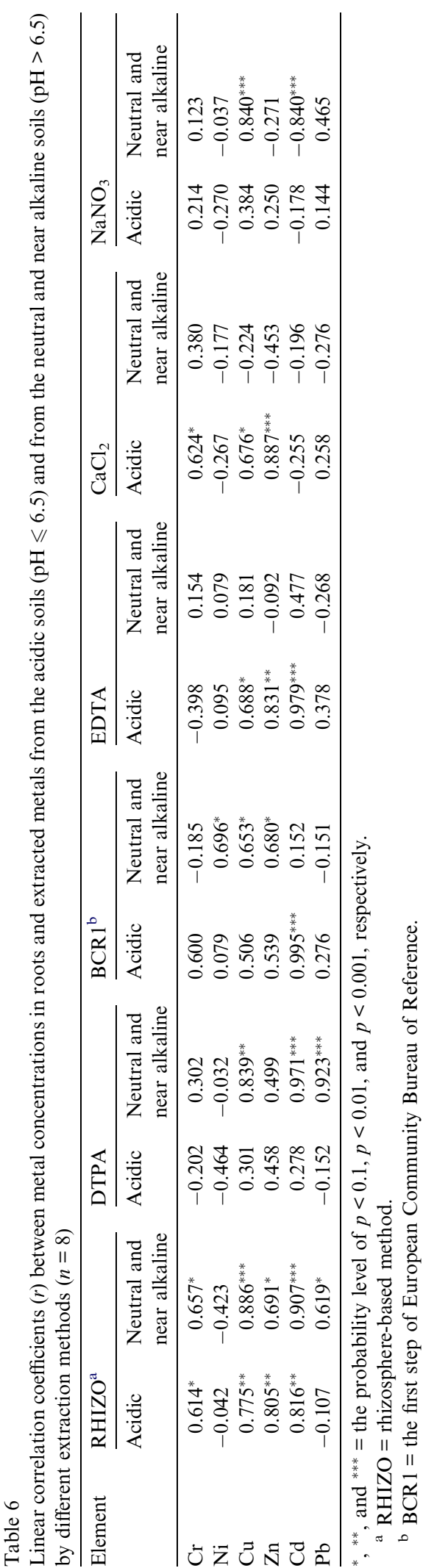


the extraction behavior of the rhizosphere-based method was similar for both types of soils, suggesting that the rhizosphere-based method simulated the soil conditions and root-soil interactions well. When the rhizospherebased method was used the extractable $\mathrm{Pb}$ from acidic soils was poorly correlated with $\mathrm{Pb}$ content of wheat roots because the concentration of organic acid used in the rhizosphere-based method was too low to extract as much $\mathrm{Pb}$ as plant needed from acidic soils. This might be so because $\mathrm{Pb}$ was organic matter-bound, iron and manganese oxides-bound in soil, which is largely unavailable to plants (Blaylock et al., 1997; Pitchel et al., 1999). However, a good correlation was observed between the extractable $\mathrm{Pb}$ from the neutral and near alkaline soils by the rhizosphere-based method and $\mathrm{Pb}$ content of wheat roots because organic acids increased the release of $\mathrm{Pb}$ from the neutral and near alkaline soils (Blaylock et al., 1997).

There was a good correlation between the DTPA extractable $\mathrm{Cu}, \mathrm{Cd}$ and $\mathrm{Pb}$ from the neutral and near alkaline soils and the metal contents of wheat roots, but poor correlation for the acidic soils. DTPA is a strong extractant for the acidic soils (O'Connor, 1988; Hammer and Keller, 2002). DTPA could extract much more divalent cations from the acidic soils due to high concentration of $\mathrm{CaCl}_{2}$ used and high $\mathrm{pH}$ of extractant solution (Hammer and Keller, 2002). Miner et al. (1997) also obtained poor correlation between plant metal concentrations and the DTPA extractable metals from acidic soils. Therefore, the DTPA extraction method is unsuitable for assessing the bioavailability of heavy metals to plants for acidic soils.

It was interesting to find that the extractable $\mathrm{Ni}, \mathrm{Zn}$, and $\mathrm{Cu}$ by BCR 1 showed a reasonably good correlation for the neutral and near alkaline soils and poor correlations for the acidic soils. In contrast, a good correlation was observed between the BCR 1 extractable $\mathrm{Cd}$ and $\mathrm{Cd}$ content of wheat roots for acidic soils. There were no clear explanations for this phenomenon.

The EDTA extractable $\mathrm{Cu}, \mathrm{Zn}$, and $\mathrm{Cd}$ had a good correlation for the acidic soils, but not for the neutral and near alkaline soils. This was easily understood because the EDTA method was originally developed for acidic soils.

The $\mathrm{CaCl}_{2}$ extractable $\mathrm{Cr}, \mathrm{Cu}$, and $\mathrm{Zn}$ had a good correlation with their contents of wheat roots for the acidic soils, but poor correlation for the neutral and near alkaline soils. The $\mathrm{NaNO}_{3}$ extractable $\mathrm{Cu}$ and $\mathrm{Cd}$ showed positive and negative correlation for the neutral and near alkaline soils, respectively. In high $\mathrm{pH}$ soils $(\mathrm{pH}>6.5)$, $\mathrm{Cd}$ desorption was increased by ligand rather than by proton such as soil electrolyte $\left(\mathrm{NO}_{3}^{-}\right.$, $\mathrm{Cl}^{-}$) (Naidu and Harter, 1998). The $\mathrm{NaNO}_{3}$ extractable Cd was low at $\mathrm{pH}$ value $>5.5$ (Naidu and Harter, 1998), which supported our results that the $\mathrm{NaNO}_{3}$ extractable $\mathrm{Cd}$ correlated negatively with root $\mathrm{Cd}$.
Based on the above comparison one can draw a conclusion that the extractable $\mathrm{Cu}, \mathrm{Zn}, \mathrm{Cr}$, and $\mathrm{Cd}$ of soils by the rhizosphere-based method were significantly correlated with the metal contents of wheat roots. For DTPA, BCR1 and EDTA methods there were relatively poor correlations between the extractable $\mathrm{Cu}, \mathrm{Zn}$ and $\mathrm{Cd}$ of soils and metal contents of wheat roots. However, it must be pointed out that the most distinct feature of the rhizosphere-based method was that the recommended method was suitable for both the acidic soils, the neutral and near alkaline soils. The DTPA, EDTA, $\mathrm{CaCl}_{2}$ and $\mathrm{NaNO}_{3}$ methods were suffered from their limited practical applicability. The DTPA and EDTA extraction methods were only suitable for calcareous or only for acidic soils, respectively. The $\mathrm{CaCl}_{2}$ and $\mathrm{NaNO}_{3}$ extraction methods were only suitable for exchangeable metals.

\subsection{Comparison of the rhizosphere-based extraction method with other extraction methods for bioavailability using stepwise multiple regression analyses}

Availability of metals to plants is affected by soil properties including soil $\mathrm{pH}$, OM, Fe-Mn oxides, CEC, and plant species (Haq et al., 1980; Li et al., 1998). Ideally, the chemical extraction methods used to predict the bioavailability of metals in soil should represent the soil-root interactions in the rhizosphere. In order to test whether the different extraction methods meet these requirements, a stepwise multiple regression analysis was performed.

It should be pointed out that the simple correlation analysis indicated that the correlations of $\mathrm{Pb}$ and $\mathrm{Ni}$ concentrations in roots with extractable $\mathrm{Pb}$ and $\mathrm{Ni}$ by all extraction methods were insignificant (Table 5). The stepwise multiple regression analysis revealed the same results. Therefore, no discussion was given in detail afterwards for $\mathrm{Pb}$ and $\mathrm{Ni}$.

The stepwise multiple regression analysis for $\mathrm{Cr}, \mathrm{Zn}$, $\mathrm{Cu}$, and $\mathrm{Cd}$ concentrations in roots as a function of extracted metals in soil solution fractions, soil $\mathrm{pH}, \mathrm{OM}$, CEC, amorphous-Fe and crystal-Fe and $\mathrm{MnO}_{2}$ are presented in the order that they were added to the equations (Table 7). For simplicity, the coefficients in the equations were omitted, whereas the negative sign of variables was maintained. The correlation coefficients, $r$, allow an evaluation of the overall prediction of bioavailability. Generally, the inclusion of soil properties variables improved the correlation coefficients to different extent for different extraction methods. It could be concluded that the equation of the rhizosphere-based method was the simplest one and no other soil properties variables needed to be added. In contrast, the DTPA, BCR1, EDTA, $\mathrm{CaCl}_{2}$ and $\mathrm{NaNO}_{3}$ extraction methods required the addition of various soil properties variables for the different metals in the equations. 
Table 7

Stepwise multiple regression equations for metals of roots as function of extractable metals by different extraction methods and soil properties

\begin{tabular}{|c|c|c|c|c|c|c|c|c|c|}
\hline \multirow[t]{2}{*}{ Method } & \multirow{2}{*}{$\begin{array}{l}\text { Regression } \\
\text { Step }\end{array}$} & \multicolumn{2}{|l|}{$\mathrm{Cd}_{\text {root }}$} & \multicolumn{2}{|l|}{$\mathrm{Cr}_{\text {root }}$} & \multicolumn{2}{|l|}{$\mathrm{Cu}_{\text {root }}$} & \multicolumn{2}{|l|}{$\mathrm{Zn}_{\text {root }}$} \\
\hline & & Variables & $r$ & Variables & $r$ & Variables & $r$ & Variables & $r$ \\
\hline $\mathrm{RHIZO}^{\mathrm{a}}$ & $\begin{array}{l}1 \\
2\end{array}$ & $\mathrm{Cd}$ & $0.796^{* * *}$ & $\mathrm{Cr}$ & $0.519^{*}$ & $\mathrm{Cu}$ & $0.731^{* * *}$ & $\begin{array}{l}\mathrm{Zn} \\
(-) \mathrm{Zn} \times \mathrm{CEC}\end{array}$ & $\begin{array}{l}0.733^{* * *} \\
0.843^{* * *}\end{array}$ \\
\hline DTPA & $\begin{array}{l}1 \\
2 \\
3\end{array}$ & $\begin{array}{l}\mathrm{Cd} \times \text { Amor-Fe } \\
(-) \mathrm{Cd} \times \mathrm{CEC} \\
(-) \mathrm{pH}\end{array}$ & $\begin{array}{l}0.801^{* * *} \\
0.875^{* * *} \\
0.899^{* * *}\end{array}$ & Cry-Fe & $0.541^{*}$ & $\begin{array}{l}\mathrm{Cu} \\
(-) \mathrm{Cu} \times \mathrm{OM} \\
(-) \mathrm{Cry}-\mathrm{Fe}\end{array}$ & $\begin{array}{l}0.524^{*} \\
0.715^{* *} \\
0.815^{* *}\end{array}$ & $\begin{array}{l}\mathrm{Zn} \\
(-) \mathrm{Zn} \times \mathrm{CEC}\end{array}$ & $\begin{array}{l}0.512^{*} \\
0.825^{* * *}\end{array}$ \\
\hline $\mathrm{BCR} 1^{\mathrm{b}}$ & $\begin{array}{l}1 \\
2 \\
3\end{array}$ & $\begin{array}{l}\mathrm{Cd} \times \text { Amor-Fe } \\
(-) \mathrm{Cd} \times \mathrm{OM} \\
(-) \mathrm{Cd} \times \mathrm{pH}\end{array}$ & $\begin{array}{l}0.800^{* * *} \\
0.889^{* * *} \\
0.937^{* * *}\end{array}$ & $\begin{array}{l}\mathrm{Cr} \times \mathrm{Cry}-\mathrm{Fe} \\
(-) \mathrm{Cr} \times \mathrm{pH} \\
(-) \mathrm{MnO}_{2}\end{array}$ & $\begin{array}{l}0.477 \\
0.697^{*} \\
0.783^{* *}\end{array}$ & $\begin{array}{l}\mathrm{Cu} \\
(-) \mathrm{Cu} \times \mathrm{CEC}\end{array}$ & $\begin{array}{l}0.541^{*} \\
0.629^{*}\end{array}$ & $\begin{array}{l}\mathrm{Zn} \\
(-) \mathrm{Zn} \times \mathrm{CEC}\end{array}$ & $\begin{array}{l}0.590^{*} \\
0.868^{* * *}\end{array}$ \\
\hline EDTA & $\begin{array}{l}1 \\
2 \\
3\end{array}$ & $\begin{array}{l}\mathrm{Cd} \times \text { Amor-Fe } \\
\text { Cry-Fe } \\
(-) \mathrm{pH}\end{array}$ & $\begin{array}{l}0.807^{* * *} \\
0.854^{* * *} \\
0.883^{* * *}\end{array}$ & $\begin{array}{l}\text { Cry-Fe } \\
(-) \mathrm{Cr} \times \mathrm{MnO}_{2}\end{array}$ & $\begin{array}{l}0.541^{*} \\
0.682^{*}\end{array}$ & ns & & $\begin{array}{l}\mathrm{Zn} \\
(-) \mathrm{Zn} \times \mathrm{OM}\end{array}$ & $\begin{array}{l}0.747^{* * *} \\
0.819^{* * *}\end{array}$ \\
\hline $\mathrm{NaNO}_{3}$ & $\begin{array}{l}1 \\
2 \\
1\end{array}$ & $\begin{array}{l}\text { Cry-Fe } \\
(-) \mathrm{Cd} \times \mathrm{Cry}-\mathrm{Fe} \\
\text { Cry-Fe }\end{array}$ & $\begin{array}{l}0.682^{* *} \\
0.749^{* *} \\
0.682^{* *}\end{array}$ & $\begin{array}{l}\mathrm{Cr} \times \mathrm{Cry}-\mathrm{Fe} \\
(-) \mathrm{Cr} \mathrm{MnO}_{2} \\
\text { Cry-Fe }\end{array}$ & $\begin{array}{l}0.615^{* *} \\
0.715^{* *} \\
0.541^{*}\end{array}$ & $\begin{array}{l}\mathrm{ns} \\
\mathrm{Cu}\end{array}$ & $0.676^{* *}$ & $\begin{array}{l}\mathrm{Zn} \\
(-) \mathrm{Zn} \times \mathrm{CEC} \\
\mathrm{ns}\end{array}$ & $\begin{array}{l}0.762^{* * * *} \\
0.861^{* * * *}\end{array}$ \\
\hline
\end{tabular}

${ }^{*},{ }^{* *}$, and ${ }^{* * *}=$ the probability level of $p<0.1, p<0.01$, and $p<0.001$, respectively. ns $=$ no significance.

${ }^{\text {a }}$ RHIZO = rhizosphere-based method.

${ }^{\mathrm{b}}$ BCR 1 = the first step of European Community Bureau of Reference.

Here we take the regression equations for $\mathrm{Cd}$ in roots as example to discuss the parameters in the equation. The extractable $\mathrm{Cd}$ by various extraction methods and soil properties variables are listed in Table 7. The equation of $\mathrm{Cd}$ of the rhizosphere-based extraction method was the simplest one with $r$ of $0.796^{* * *}$. However, the regression equations developed for root $\mathrm{Cd}$ with the DTPA, BCR1, EDTA, $\mathrm{CaCl}_{2}$, and $\mathrm{NaNO}_{3}$ extractable $\mathrm{Cd}$ required additional soil properties variables to be entered. For DTPA the first variable was $\mathrm{Cd} \times$ amorphous-Fe, the second variable $\mathrm{Cd} \times \mathrm{CEC}$ and the third variable soil $\mathrm{pH}$, which resulted in correlation coefficients of $0.801^{* * *}, 0.875^{* * *}$ and $0.899^{* * *}$, respectively. According to the data of Table 7 the equation of the DTPA extractable $\mathrm{Cd}$ is as following:

$\mathrm{Cd}$ in wheat $\operatorname{root}=1365+8.38 \mathrm{Cd} \times$ amorphous-Fe $-0.12 \mathrm{Cd} \times \mathrm{CEC}-49 \mathrm{pH}$

The addition of the second variable CEC led to negative coefficient. It means that extractable $\mathrm{Cd}$ from soils of high cation exchange capacity was less available to roots, and this effect was more pronounced if the extractable Cd was high. This observation was in agreement with the findings of Buchter et al. (1989), higher CEC soils retained greater quantities of the cation species than low CEC soils did (Elzinga et al., 1999).

For equation of the extractable Cd by BCR 1 method, the first variable was $\mathrm{Cd} \times$ amorphous- $\mathrm{Fe}$, the second and third variables entered were $\mathrm{Cd} \times \mathrm{OM}$ and $\mathrm{Cd} \times \mathrm{pH}$ interactions. The negative coefficients suggested that the extractable Cd was less available to roots when the soil $\mathrm{OM}$ and soil $\mathrm{pH}$ were high. It is understood that organic matter bound metals are less available to plants (Del Castilho et al., 1993). For EDTA extraction method the first, second, and third variables were $\mathrm{Cd} \times$ amorphous-Fe, crystal-Fe, and soil $\mathrm{pH}$. These variables resulted in EDTA extraction method with correlation coefficients of $0.807^{* * *}, 0.854^{* * *}$ and $0.883^{* * *}$, respectively. For $\mathrm{NaNO}_{3}$ extraction method the first variable was crystal-Fe. For $\mathrm{CaCl}_{2}$ extraction method the first and the second variables were crystal-Fe and $\mathrm{Cd} \times$ crystal-Fe extractable $\mathrm{Cd}$, which resulted in $r$ of $0.682^{* *}$ and $0.749^{* *}$, respectively.

Miner et al. (1997) also reported that soil properties needed to be included in the best fit to multiple regression models to improve the relationship between plant metal concentrations and soil-extractable metals for EDTA and DTPA extraction methods. In the present study, the equations of the rhizosphere-based method were the simplest ones for bioavailability.

\section{Conclusion}

Based on the aforementioned systematic comparison between the rhizosphere-based method and the DTPA, BCR1, EDTA, $\mathrm{CaCl}_{2}$ and $\mathrm{NaNO}_{3}$ extraction methods one can conclude that the rhizosphere-based method was the most robust one and it was able to properly predict the bioavailability of $\mathrm{Cr}, \mathrm{Cu}, \mathrm{Zn}$, and $\mathrm{Cd}$ in soils to 
plants, but it failed at assessing the bioavailability of two out of the six studied metals, i.e. Ni and Pb. The DTPA and BCR 1 extraction methods were good for assessing the bioavailability of $\mathrm{Cu}, \mathrm{Zn}$ and $\mathrm{Cd}$ although the correlation coefficients of $\mathrm{Cu}$ and $\mathrm{Zn}$ were relatively lower. While the EDTA extraction method was also good for assessing the bioavailability of $\mathrm{Zn}$ and $\mathrm{Cd}$, and the $\mathrm{CaCl}_{2}$ extraction method was able to assess the bioavailbility of $\mathrm{Cr}$ and $\mathrm{Zn}$. The most important feature of the rhizosphere-based method was that the suggested method was suitable for acidic, neutral and near alkaline soils. In contrast, the DTPA and EDTA extraction methods were suitable only for calcareous and only for acidic soils, respectively. The $\mathrm{CaCl}_{2}$ and $\mathrm{NaNO}_{3}$ extraction methods were only suitable for exchangeable metals. The results obtained ascertain that the rhizosphere-based extraction method simulates the rhizosphere conditions and takes into account the effect of soil-root interactions as a whole, at least to some extent. Thus, more widespread application of the rhizospherebased extraction method for bioavailability of heavy metals in soils to plants is promising. Of course, none of the methods was tested against field-grown plants.

\section{Acknowledgment}

The study was supported by the National Natural Science Foundation of China (grant Nos. 20177030, 20237010).

\section{References}

Bermond, A., Yousfi, I., Ghestem, J.P., 1998. Kinetic approach to the chemical speciation of trace metals in soils. Analyst $123,785-789$.

Blakemore, L.C., Searle, P.L., Daly, B.K., 1987. New Zealand Bureau scientific Report No. 80: Methods for chemical analysis of soils. NZ Soil Bureau: Lower Hutt, New Zealand.

Blaylock, M.J., Salt, D.E., Dushenkov, S., Zakharova, O., Gussman, C., Kapulnik, Y., Ensley, B.D., Raskin, I., 1997. Enhanced accumulation of $\mathrm{Pb}$ in Indian Mustard by soilapplied chelating agents. Environ. Sci. Technol. 31, 860865.

Buchter, B., Davidoff, B., Amacher, M.C., Hinz, C., Iskandar, I.K., Selim, H.M., 1989. Correlation of Freundlich $K_{\mathrm{d}}$ and $n$ retention parameters with soils and elements. Soil Sci. 148, 370-379.

Chaignon, V., Sanchez-Neira, I., Herrmann, P., Jaillard, B., Hinsinger, P., 2003. Copper bioavailability and extractability as related to chemical properties of contaminated soils from a vine-growing area. Environ. Pollut. 123, 229-238.

Cieśliński, G., van Rees, K.C.J., Szmigielska, A.M., Krishnamurti, G.S.R., Huang, P.M., 1998. Low-molecular-weight organic acids in rhizosphere soils of durumwheat and their effect on cadmium bioaccumulation. Plant Soil 203, 109117.
Collins, R.N., Merrington, G., McLaughlin, M.J., Morel, J.L., 2003. Organic ligand and $\mathrm{pH}$ effects on isotopically exchangeable cadmium in polluted soils. Soil Sci. Soc. Am. J. 67, 112-121.

Del Castilho, P., Chardon, W.J., Salomons, W., 1993. Influence of cattle-manure slurry application on the solubility of cadmium, copper, and zinc in a manured acidic, loamy-sand soil. J. Environ. Qual. 22, 689-697.

Elzinga, E.J., Van Grinsven, J.J.M., Swartjes, F.A., 1999. General purpose Freundlich isotherms for cadmium, copper and zinc in soils. Eur. J. Soil Sci. 50, 139-149.

Errécalde, O., Campbell, P.G.C., 2000. Cadmium and zinc bioavailability to Selenastrum capricornutum (Chloropyceae): accidental metal uptake and toxicity in the presence of citrate. J. Phycol. 36, 473-483.

Gleyzes, C., Tellier, S., Astruc, M., 2002. Fractionation studies of trace elements in contaminated soils and sediments: a review of sequential extraction procedures. Trends Anal. Chem. 21, 451-467.

Gong, Z.T., 1999. Chinese Soil Taxonomy. Chinese academic press, Beijing, China.

Gupta, S.K., Aten, C., 1993. Comparison and evaluation of extraction media and their suitability in a simple model to predict the biological relevance of heavy metal concentrations in contaminated soils. Int. J. Environ. Anal. Chem. 51, 25-46.

Hammer, D., Keller, C., 2002. Changes in the rhizosphere of metal-accumulating plants evidenced by chemical extractants. J. Environ. Qual. 31, 1561-1569.

Han, F., Shan, X.Q., Zhang, J., Xie, Y.N., Pei, Z.G., Zhang, S.Z., Zhu, Y.G., Wen, B., in press. Organic Acids Promote the Uptake of Lanthanum by Barley Roots.

Haq, A.U., Bates, T.E., Soon, Y.K., 1980. Comparison of extractants for plant-available zinc, cadmium, nickel, and copper in contaminated soils. Soil Sci. Soc. Am. J. 44, 772777.

Hendershot, W.H., Duquette, M.A., 1986. Simple barium chloride method for determining cation exchange capacity and exchangeable cations. Soil Sci. Soc. Am. J. 50, 606608.

Hudson, R.J.M., 1998. Which aqueous species control the rates of trace metal uptake by aquatic biota. Observations and predictions of non-equilibrium effects. Sci. Total Environ. 219, 95-115.

Jones, D.L., 1998. Organic acids in the rhizosphere-a critical review. Plant Soil 205, 25-44.

Li, F.L., Shan, X.Q., Zhang, T.H., Zhang, S.Z., 1998. Evaluation of plant availability of rare earth elements in soils by chemical fractionation and multiple regression analysis. Environ. Pollut. 102, 269-277.

Li, Y.H., Huang, B.X., Shan, X.Q., 2003. Determination of low molecular weight organic acids in soil, plants, and water by capillary zone electrophoresis. Anal. Bioanal. Chem. 375, $775-780$.

Lindsay, W.L., Norvell, W.A., 1978. Development of a DTPA soil test for zinc, iron, manganese, and copper. Soil Sci. Soc. Am. J. 42, 421-428.

López-Bucio, J., Nieto-Jacobo, M.F., Ramírez-Rodríguez, V., Herrera-Estrella, L., 2000. Organic acid metabolism in plants: from adaptive physiology to transgenic varieties for cultivation in extreme soils. Plant Sci. 160, 1-13. 
McBride, M.B., Nibarger, E.A., Richards, B.K., Steenhuis, T., 2003. Trace metal accumulation by red clover grown on sewage sludge-amended soils and correlation to Mehlich 3 and calcium chloride-extractable metals. Soil Sci. 168, 2938.

McLaughlin, J.M., Smolders, E., Merckx, R., Maes, A., 1997. In: Ando, T., Fujita, K., Mae, T., Matsumoto, H., Mori, S., Sekija, J. (Eds.), Plant Nutrition for Sustainable Food Production and Environment: Plant Uptake of $\mathrm{Cd}$ and $\mathrm{Zn}$ in Chelator-buffered Nutrient Solution depends on Ligand Type. Kluwer Academic Publishers, Dordrecht, The Netherlands, pp. 113-118.

Miner, G.S., Gutierrez, R., King, L.D., 1997. Soil factors affecting plant concentrations of cadmium, copper, and zinc on sludge-amended soils. J. Environ. Qual. 26, 989-994.

Morel, F.M.M., 1983. Principles of Aquatic Chemistry. John Wiley \& Sons, New York.

Naidu, R., Harter, R.D., 1998. Effect of different organic ligands on cadmium sorption by and extractability from soils. Soil Sci. Soc. Am. J. 62, 644-650.

Nelson, D.W., Sommers, L.E., 1982. Total carbon, organic carbon, and organic matter. In: Page, A.L., et al. (Eds.), Methods of Soil Analysis: Total Carbon, Organic Carbon, and Organic Matter, Part 2, 2nd ed. ASA and SSSA, Madison, WI, pp. 539-579.

Norvell, W.A., 1984. Comparison of chelating agents as extractants for metals in diverse soil materials. Soil Sci. Soc. Am. J. 48, 1285-1292.

Novozamsky, I., Lexmond, T.H.M., Houba, V.J.G., 1993. A single extraction procedure of soil for evaluation of uptake of some heavy metals by plants. Int. J. Environ. Anal. Chem. 51, 47-58.

O'Connor, G.A., 1988. Use and misuse of the DTPA soil test. J. Environ. Qual. 17, 715-718.

Payá-Pérez, A., Sala, J., Mousty, F., 1993. Comparison of ICPAES and ICP-MS for the analysis of trace elements in soil extracts. Int. J. Environ. Anal. Chem. 51, 223-230.

Pitchel, J., Kuroiwa, K., Sawyerr, H.T., 1999. Distribution of $\mathrm{Pb}, \mathrm{Cd}$, and $\mathrm{Ba}$ in soils and plants of two contaminated soils. Environ. Pollut. 110, 171-178.

Qian, J., Shan, X.Q., Wang, Z.J., Tu, Q., 1996. Distribution and plant availability of heavy metals in different particlesize fractions of soils. Sci. Total Environ. 187, 131-141.

Qin, F., Shan, X.Q., Wen, B., 2004. Effects of low-molecularweight organic acids and residence time on desorption of $\mathrm{Cu}, \mathrm{Cd}$, and $\mathrm{Pb}$ from soils. Chemosphere 57, 253-263.

Quevauviller, Ph., Rauret, G., Muntau, H., Ure, A.M., Rubio, R., Lopez-sanchez, J.F., Fiedler, H.D., 1994. Evaluation of a sequential extraction procedure for the determination of extractable trace metal contents in sediment. Fres. J. Anal. Chem. 349, 808-814.
Ryan, P.R., Delhaize, E., Jones, D.L., 2001. Function and mechanism of organic anion exudation from plant roots. Ann. Rev. Plant Physiol. Plant Mol. Biol. 52, 527560.

Sauvé, S., Cook, N., Hendershot, W.H., McBride, M.B., 1996. Linking plant tissue concentrations and soil copper pools in urban contaminated soils. Environ. Pollut. 94, 153157.

Shan, X.Q., Lian, J., Wen, B., 2002. Effect of organic acids on adsorption and desorption of rare earth elements. Chemosphere 47, 701-710.

Shan, X.Q., Wang, Z.W., Wang, W.S., Zhang, S.Z., Wen, B., 2003. Labile rhizosphere soil solution fraction for prediction of bioavailability of heavy metals and rare earth elements to plants. Anal. Bioanal. Chem. 375, 400-407.

Shuman, L.M., 1982. Separation soil iron and manganese oxide fractions for microelement analysis. Soil Sci. Soc. Am. J. 46, 1099-1102.

Strobel, B.W., 2001. Influence of vegetation on low-molecularweight carboxylic acids in soil solution - a review. Geoderma 99, 169-198.

Ure, A.M., Quevauviller, Ph., Muntau, H., Griepink, B., 1993. Speciation of heavy metals in soils and sediments. An account of the improvement and harmonization of extraction techniques undertaken under the auspices of the BCR of the commission of the European communities. Int. J. Environ. Anal. Chem. 51, 135-151.

Wang, Z.W., Zhang, S.Z., Shan, X.Q., 2004. Effects of lowmolecular-weight organic acids on uptake of lanthanum by wheat roots. Plant Soil 261, 163-170.

Wear, J.I., Evans, C.E., 1968. Relationship of zinc uptake by corn and sorghum to soil zinc measured by three extractants. Soil Sci. Soc. Am. Proc. 32, 543-546.

Whalley, C., Grant, A., 1994. Assessment of the phase selectivity of the European community Bureau of Reference (BCR) sequential extraction procedure for metals in sediment. Anal. Chim. Acta 291, 287-295.

Whitten, M.G., Ritchie, G.S.P., 1991. Cadmium chloride extractable cadmium as an estimate of cadmium uptake by subterranean clover. Aust. J. Soil Res. 29, 215-221.

Zhang, S.Z., Shan, X.Q., 1997. The determination of rare earth elements in soil by inductively coupled plasma mass spectrometry. At. Spectrosc. 18, 140-144.

Zhang, H., Davison, W., Knight, B., McGrath, S., 1998. In situ measurements of solution concentrations and fluxes of trace metals in soils using DGT. Environ. Sci. Technol. 32, 704 710.

Zhang, H., Zhao, F.J., Sun, B., Davison, W., McGrath, S.P., 2001. A new method to measure effective soil solution concentration predicts copper availability to plants. Environ. Sci. Technol. 35, 2602-2607. 